\title{
Transmission of Garlic virus B, Garlic virus C, Garlic virus D and Garlic virus $X$ by Aceria tulipae (Keifer) in leek
}

\author{
Elżbieta Dąbrowska (D) • Mariusz Lewandowski • \\ Sylwia Koczkodaj • Elżbieta Paduch-Cichal
}

Accepted: 10 February 2020 /Published online: 19 March 2020

(C) The Author(s) 2020

\begin{abstract}
Viruses belonging to genus Allexivirus infest garlic and are spread via propagation material and through a vector, the eriophyid mite Aceria tulipae (Keifer). The research material was garlic bulbs originating from Poland, available commercially on the Polish retail market. The aim of this study was to assess the possibility of transmission of Garlic virus B (GarV-B), Garlic virus C (GarV-C), Garlic virus D (GarV-D) and Garlic virus X (GarV-X) from garlic bulbs to leek plants by its vector, A. tulipae. These allexiviruses were detected in garlic bulbs and in leek leaves on which transferred mites fed. There was a high similarity of the genetic structure in the isolates of GarV-B, GarV-C, GarV-D and GarV-X collected from garlic bulbs and the isolates collected from the leek plants. The results of the study showed for the first time the potential of GarVB, GarV-C, GarV-D and GarV-X to infect leek plants and constitutes the first attempt to examine the ability of A. tulipae to transmit these viruses from garlic to leeks.
\end{abstract}

Keywords Allexiviruses · Aceria tulipae · Garlic · RTPCR technique $\cdot$ Virus transmission

\footnotetext{
E. Dąbrowska $(\bowtie) \cdot$ S. Koczkodaj $\cdot$ E. Paduch-Cichal Section of Phytopathology, Department of Plant Protection, Warsaw University of Life Sciences - SGGW (WULS-SGGW), Nowoursynowska 159, 02-776 Warsaw, Poland

e-mail: elzbieta_dabrowska@sggw.pl

M. Lewandowski

Section of Applied Entomology, Department of Plant Protection, Warsaw University of Life Sciences - SGGW (WULS-SGGW), Nowoursynowska 159, 02-776 Warsaw, Poland
}

\section{Main text}

Garlic (Allium sativum L.) is an important culinary plant that is cultivated throughout the world (Krzymińska 2008). The most severe threat to garlic crops is posed by viruses. The majority of garlic cultivars do not produce seeds, therefore garlic reproduction is only vegetative, i.e. by cloves and aerial bulblets (Etoh 1985; Simon and Jenderek 2003). It is commonly believed that plant species with vegetative reproduction are particularly threatened by viral diseases. Moreover, during cultivation or garlic bulb storage viruses can be transmitted by vectors such as insects (aphids) or arachnids (mites) (King et al. 2012). In garlic plants different virus species of the following genera were detected: Potyvirus, Carlavirus, Cucumovirus (Stefanac 1980), Tobravirus (Van Dijk 1993), Tobamovirus (Sako et al. 1991), Cytorhabdovirus (Sward 1990), Nepovirus (Van Dijk 1993), Tospovirus (Bag et al. 2009) and Macluravirus (Walkey 1990).

One of the most significant threats to garlic crops are virus species in the genus Allexivirus. A total of eight species have been described in this genus: Garlic miteborne filamentous virus (GarMbFV), Garlic virus A (GarV-A), Garlic virus B (GarV-B), Garlic virus $C$ (GarV-C), Garlic virus D (GarV-D), Garlic virus $E$ (GarV-E), Garlic virus X (GarV-X), and Shallot virus $X$ (ShVX) (The ICTV Online (10th) Report on Virus Taxonomy 2016). The genome of allexiviruses is composed of a single molecule of (+)-strand ssRNA. The size of the genome depends on the virus species and varies from 8000 to 9000 nucleotides (nt) (Chen and 
Chen 2002; Adams et al. 2004). In the allexivirus genome six open reading frames (ORF) have been identified (Adams et al. 2004).

Allexiviruses have been detected in garlic plants in different parts of the world: Africa (Jemal et al. 2015), North America (Gieck et al. 2009), South America (Cafrune et al. 2006; Mituti et al. 2015), Australia (Takaichi et al. 2001; Wylie et al. 2012; Singh et al. 2014), Europe (Lanzoni et al. 2006; Klukáčková et al. 2007; Chodorska et al. 2014) and New Zealand (Ward et al. 2009). These viruses infect plants of the Allium species (A. caeruleum, A. cepa, A. fistulosum, A. sativum, A. ascalonicum, A. porrum and A. vineale) (Van Dijk et al. 1991; Van Dijk and Van der Vlugt 1994; Shahraeen et al. 2008; Bereda and Paduch-Cichal 2016). The occurrence of allexiviruses in garlic crops results in the worsening of yield quality, causing decreases in bulb diameter and bulb weight. It has also been reported that the negative effect on yield quality increased when the plant was infected by other viruses (Cafrune et al. 2006; Perotto et al. 2010). It is relatively rare for garlic plants to be infected by a single allexivirus, with mixed infections involving from two to six different species being the most frequent (Fujisawa 1989; Conci et al. 1992; Van Dijk 1993; Chodorska et al. 2014). Allexiviruses are spread with propagation material and transmitted by mites during the vegetation period, especially during the storage of garlic bulbs (Van Dijk et al. 1991; Yamashita et al. 1996; Koo et al. 1998; Kang et al. 2007; Granda et al. 2017).

One of the most dangerous pests of garlic and an important vector of allexiviruses is Aceria tulipae (Keifer) (Acariformes: Eriophyoidea). This mite species is commonly detected on young garlic leaves, but it can also feed and develop under the scales and on plump cloves on which withering and matt brown spots may appear (Jeppson et al. 1975; Keifer et al. 1982). This eriophyid mite species can cause severe loss of garlic bulbs, reducing yields by up to $23 \%$. Most damage caused by A. tulipae occurs during the storage of garlic bulbs (Larrain 1986). Aceria tulipae was detected in garlic plants in Africa (Hassan et al. 1986), North America (Flechtmann and Davis 1971), South America (Rossetto 1972; González et al., 1973; Almaguel et al. 1986), Asia (Charanasri et al. 1984; Bala et al. 2015), Europe (Liro and Roivainen 1951; Boczek and Chyczewski 1974; Knaub and Buslawa 1975; del Estal et al. 1985; Courtin et al. 2000; Sapáková et al. 2012) and New Zealand (Manson 1970).
According to the existing literature, only a few researchers have attempted to describe the mechanism of virus transmission by eriophyid mites. Wheat streak mosaic virus (WSMV) is transmitted by larvae, nymphae and adults of Aceria tosichella Keifer, but not through eggs. However, the adults transmit WSMV only if they acquired it during their immature stages; they cannot acquire the virus as adults and then transmit it (Orlob 1966). Paliwal (1980) detected particles of WSMV in haemocoel and salivary glands, and suggested that WSMV may be transmitted by A. tosichella in a semipersistent manner. Proeseler $(1969,1972)$ reported that Fig mosaic virus (FMV) was transmitted in a persistent manner. According to the results obtained by Kulkarni et al. (2002), Pigeon pea sterility mosaic virus (PPSMV) was transmitted in a semi-persistent mode by Aceria cajani ChannaBaswanna. Studies of Peach mosaic virus (PMV) and Ryegrass mosaic virus (RMV) and other mite-transmitted viruses also indicated a semi-persistent mode of transmission (Slykhuis and Paliwal, 1972; Gispert et al. 1998). The mechanism of acquisition and transmission of viruses belonging to the Allexivirus genus by eriophyid mites has not been described yet.

The aim of the research was to examine the transmission of GarV-B, GarV-C, GarV-D and GarV-X from garlic bulbs to leek plants by A. tulipae. Leek plants were used as test subjects for several reasons. First, leek plants are a very common host plant of A. tulipae (Kiedrowicz et al. 2017). Second, the use of seedling leek plants ensures that the material has not been infected by allexiviruses, as they are not transmitted by the seeds (Bereda and Paduch-Cichal 2016). Finally, previous studies conducted by Shahraeen et al. (2008) have confirmed the presence of GarV-D, GarV-B and GarV-C in leek plants grown in Iran.

The study on the transmission of GarV-B, GarV-C, GarV-D and GarV-X by mites was preceded by the search for garlic bulbs infected by the aforementioned viruses. To perform the study, several garlic bulbs were collected from retail stores in Warsaw, Central Poland. Following observation with a stereomicroscope, three bulbs inhabited by more than 50 specimens of $A$. tulipae were selected. These bulbs were tested for the presence of allexiviruses using the reverse-transcription polymerase chain reaction (RT-PCR) technique. In all of these garlic samples GarV-B, GarV-D and GarV-X were detected, and one of them was also infected with GarV-C (Table 1). No evidence of GarV-A, GarV-E, ShVX, and GarMbFV were found in any of the bulbs. 
Table 1 GarV-B, GarV-C, GarV-D and GarV-X detected in garlic bulbs and leek plants

\begin{tabular}{|c|c|c|c|c|c|}
\hline \multirow{2}{*}{ No. Transmission } & \multirow{2}{*}{ Sample } & \multicolumn{4}{|c|}{ Viruses } \\
\hline & & GarV-B & GarV-C & GarV-D & GarV-X \\
\hline \multirow{6}{*}{$\mathrm{T} 1$} & $\begin{array}{c}\text { Garlic bulb } \\
\text { MP1 }\end{array}$ & $++^{\mathrm{b}}$ & - & + & + \\
\hline & $\begin{array}{c}\text { Leek plants } \\
\mathrm{P}^{\mathrm{a}}\end{array}$ & $-^{c}$ & - & - & + \\
\hline & P2 & + & - & + & + \\
\hline & P3 & + & - & + & + \\
\hline & P4 & - & - & + & + \\
\hline & P5 & + & - & + & + \\
\hline \multirow{6}{*}{$\mathrm{T} 2$} & $\begin{array}{c}\text { Garlic bulb } \\
\text { MP2 }\end{array}$ & + & - & + & + \\
\hline & $\begin{array}{l}\text { Leek plants } \\
\text { P6 }\end{array}$ & + & - & + & + \\
\hline & $\mathrm{P} 7$ & + & - & - & + \\
\hline & P8 & + & - & + & + \\
\hline & P9 & + & - & + & + \\
\hline & $\mathrm{P} 10$ & + & - & + & - \\
\hline \multirow{6}{*}{$\mathrm{T} 3$} & $\begin{array}{c}\text { Garlic bulb } \\
\text { BP3 }\end{array}$ & + & + & + & + \\
\hline & $\begin{array}{l}\text { Leek plants } \\
\text { P11 }\end{array}$ & + & + & + & + \\
\hline & $\mathrm{P} 12$ & + & + & + & + \\
\hline & P13 & + & + & + & + \\
\hline & P14 & + & + & + & + \\
\hline & $\mathrm{P} 15$ & + & + & + & + \\
\hline $\begin{array}{l}\text { Total (number of plants } \\
\text { transmitted/inoculated) }\end{array}$ & & $13 / 15$ & $5 / 5$ & $13 / 15$ & $14 / 15$ \\
\hline$\%$ of positive results & & 86.7 & 100 & 86.7 & 93.3 \\
\hline
\end{tabular}

${ }^{\text {a }} \mathrm{P} n$ - number of leek plant samples after the feeding of mites

$\mathrm{b}_{+}-$virus detected

c - no virus detected

cells highlighted in grey - sequenced and submitted to the GenBank samples

Cloves of these bulbs were separated from the bulbs and external scales were removed. Then the cloves were placed in petri dishes with an $8 \mathrm{~cm}$ diameter. The petri dishes were placed in three separate transparent plastic containers covered with a transparent thick-weaved material and tied with a rubber band. The containers were stored for 14 days inside a Sanyo MRL-350H climate chamber (Sanyo Electric, Moriguchi, Japan) at $22{ }^{\circ} \mathrm{C}$ with $50-60 \%$ RH, under a 4200 lx light intensity and with a $16-\mathrm{h}$ photoperiod.
To establish A. tulipae populations on leek plants, adult forms of the mites were transferred from each of the aforementioned three populations detected on garlic bulbs onto five allexivirus-free leek plants, 20 specimens for each plant. The plants were grown in $5-\mathrm{cm}$ pots in a potting soil mixture. Healthiness of these leek plants was confirmed by RT-PCR. The transfer of mites was conducted using a preparation needle with an attached eyelash according to the procedure described by de Lillo et al. (2010). There were three transmission sets (which will be referred to as T1, T2 and T3). In each set 
five different leek plants were used, with the total number of plants used in the study amounting to 15. Each consecutive transmission occurring a week after the previous one. Plants were placed in isolators made from bolting cloth in $40 \mu \mathrm{m}$ mesh size. The plants were kept in the Sanyo MRL-350H climate chamber for two weeks and watered every $24 \mathrm{~h}$. Plants were grown at $22{ }^{\circ} \mathrm{C}$ temperature, 50-60\% RH and at a light intensity of $4200 \mathrm{~lx}$ with 16-h photoperiod. After two weeks following each transmission, leek plant tissues were tested for the presence of all known allexiviruses using the RT-PCR technique.

To detect and identify the isolates of GarV-A, GarVB, GarV-C, GarV-D, GarV-E, GarV-X, ShVX and GarMbFV in the three garlic bulbs and leek plants, RTPCR with total RNA and appropriate primers was applied. Total RNA was extracted from garlic bulbs and leek tissues using the silica capture (SC) method described originally by Boom et al. (1990) and next adapted to the detection of plant viruses by Malinowski (1997). RNA extracts were subjected to amplification by RT-PCR using the Transcriptor One-Step RT-PCR Kit (Roche Applied Science, Germany). RNA obtained from garlic bulb BP3 was used as a positive control and nuclease-free water was used as a negative control.

Primer pairs designed by Bereda et al. (2017), amplifying the coat protein gene $(\mathrm{CP})$ and the nucleic acid binding protein (NABP) of GarMbFV, GarV-A, GarV-B and GarV-D were used. Primers for ShVX were specific to the part of the CP and also designed by Bereda et al. (2017). Other primer pairs were designed by Bereda (2015). Primer pairs for GarV-X detection was specific to the $420 \mathrm{nt}$ part of replicase protein gene (RdRp). Primer pairs applied for detection of GarV-E and GarV-C were designed in the part of hypothetical protein (HP) or in the part of CP and NABP, respectively.

The samples were subjected to reverse transcription for $30 \mathrm{~min}$ at $50{ }^{\circ} \mathrm{C}, 2 \mathrm{~min}$ of denaturation at $94{ }^{\circ} \mathrm{C}$, followed by 35 cycles of $30 \mathrm{~s}$ of denaturation at $94{ }^{\circ} \mathrm{C}$, $45 \mathrm{~s}$ of annealing (the temperature for each virus was different according to Bereda (2015) and Bereda et al. (2017)) and $45 \mathrm{~s}$ elongation at $68{ }^{\circ} \mathrm{C}$ with the final extension of $7 \mathrm{~min}$ at $68^{\circ} \mathrm{C}$. The reaction products were resolved by electrophoresis in the TBE buffer in $1.2 \%$ agarose gel. The nucleotide sequences of GarV-B, GarV-C, GarV-D and GarV-X detected in garlic bulbs and leek plants were determined using ABI 3730 Genetic Analyzer (Applied Biosystems, Foster City, CA). Sequence data were assembled using DNA Baser
Sequence Assembler ver. 5.15 (Heracle BioSoft SRL, Romania). Sequence alignments were constructed in MEGA ver. 5 (Tamura et al. 2011). Sequence similarity and identity of the studied parts of the genome of the Polish isolates of GarV-B, GarV-C, GarV-D and GarV$\mathrm{X}$ and of a reference isolate for each virus from GenBank was performed in BioEdit (Hall 1999).

The results of the research on transmission of GarVB, GarV-C, GarV-D and GarV-X from garlic bulbs to leek plants by A. tulipae are presented in Table 1. GarV$B$ was detected in three of five leek plants from the first transmission set and in all leek plants from the second and third transmission sets. In total, $86.7 \%$ of leek samples tested positive for GarV-B. GarV-C was detected in all leek samples from only one transmission set. However, GarV-C was not found in garlic bulbs from which adults of $A$. tulipae were transferred to leek plants in the remaining two sets. GarV-D was detected in four of five leek plant samples from transmission sets one and two and in five of five leek plant samples from transmission set three. As with GarV-B, 86.7\% of leek samples tested positive for GarV-D. GarV-X was detected in five of five leek plant samples in transmission sets one and three and in four of five leek samples in transmission set two. In total, $93.3 \%$ of leek plant samples tested positive for GarV-X. GarV-A, GarV-E, GarMbFV and ShVX were not detected in any of the leek plants. However, these four viruses were not present in garlic bulbs on which populations of $A$. tulipae were held before mites were transferred to leek plants.

Isolates of each detected virus were sequenced and the sequences were deposited in GenBank and assigned accession numbers: MN175534-MN175538 for GarVB isolates, MN175539 and MN175540 for GarV-C isolates, MN167132-MN167137 for GarV-D isolates and MN175541-MN175546 for GarV-X isolates. The comparative molecular analyses were performed based on the sequences of the CP and NABP of the six Polish GarV-B isolates and the one Argentinian isolate retrieved from GenBank (NC_025789.1); on the sequences of the part of $\mathrm{CP}$ and NABP of the two Polish GarV-C isolates and the one Japanese isolate retrieved from GenBank (NC_003376.1); on the sequences of CP and NABP of the six Polish GarV-D isolates and the one Australian isolate retrieved from GenBank (NC_022961.1) and on the sequences of the part of replicase protein of the six Polish isolates of GarV-X and the one Korean isolate retrieved from GenBank (NC_001800.1). In all six Polish GarV-B isolates, the 
length of the obtained nucleotide sequences was 1155 nucleotides (nt). Each had two coding fragments: CP (735 nt) and NABP (384 nt) with a small intron between them $(17 \mathrm{nt})$. The isolates shared an nt identity of $99.8 \%$ in the CP region and $99.7-100 \% \mathrm{nt}$ in the NABP region. The comparison of the amino acid (aa) sequences of the $\mathrm{CP}$ and the NABP of the Polish virus isolates indicated an identity of $100 \%$. The Polish GarV-B isolates and the Argentinian isolate (NC_025789.1) shared a 91.794.8\% nt and a 95-97.9\% aa in the CP region identity. The nucleotide and the amino acid identity in the NABP region equaled $90.6-94 \% \mathrm{nt}$ and $89.7-97.6 \%$ aa. The length of the amplicon sequence of two Polish GarV-C isolates was $627 \mathrm{nt}$. Both sequences included part of the $\mathrm{CP}$ coding sequence (426 nt), a small intron (15 nt) and part of the NABP coding sequence (186 nt). The Polish GarV-C isolates showed a $99.2 \%$ nt and a $98.5 \%$ aa identity in the part of the CP. Nucleotide and amino acid identity of the two Polish GarV-C isolates was $100 \%$ in the partial NABP sequences. The Polish GarV-C isolates and the Japanese isolate (NC_003376.1) shared a 90.6-90.8\% nt and a 96.4-97.1\% aa in the CP region identity. The nucleotide and the amino acid identity in the NABP region were $90.8 \%$ nt and $95.1 \%$ aa. In the six Polish GarV-D isolates, the length of the nucleotide sequences obtained was $1139 \mathrm{nt}$ (with $753 \mathrm{nt}$ coding CP region and $387 \mathrm{nt}$ coding NABP region). The isolates shared an identity of $98.6-99 \%$ nt and $99.2-100 \%$ aa in the CP region, and $99.4-99.7 \%$ nt and $100 \%$ aa in the NABP region. The isolates from Poland and the Australian isolate (NC_022961.1) shared a 93.3-95.6\% nt and a $96.4-99.2 \%$ aa sequence identity in the $\mathrm{CP}$ region. In the NABP region the nucleotide and the amino acid identity of the Polish GarV-D isolates and the Australian isolate equaled $93.2-96.3 \% \mathrm{nt}$ and $92.9-95.3 \%$ aa. The length of the nucleotide sequences of the six Polish GarV-X isolates was $420 \mathrm{nt}$ and the they shared a 99.5\% nt and a $100 \%$ aa identity in the part of the RdRp. The Polish GarV-X isolates and the Korean isolate (NC_001800.1) shared 92.1-97.6\% nt and a 96.4$97.8 \%$ aa in the part of the RdRp identity. The conducted nt- and aa-based comparative molecular analyses of the selected genome parts of GarV-B, GarV-C, GarV-D, GarV-X and four reference sequences retrieved from GenBank (one for each virus) confirmed the pathogens detected in garlic bulbs and leek plants to be GarV-B, GarV-C, GarV-D and GarV-X.

According to previous reports, the existence of numerous A. tulipae populations on garlic plants showing chlorotic streaking and leaf curling has been associated with the ability of the mites to transmit allexiviruses (Yamashita et al. 1996; Koo et al. 1998; Kang et al. 2007; Granda et al. 2017). In the case of GarMbFV, it was proven that the colonization of healthy garlic plants by A. tulipae obtained from infected bulbs resulted in the presence of the virus in the bulbs tested (Yamashita et al. 1996; Koo et al. 1998), which corresponds with the results obtained by Kang et al. (2007) for GarV-B. According to Granda et al. (2017), the incidence of numerous mite populations in garlic crops in the Alausí area (Chimborazo Province, Ecuador) may indicate that A. tulipae is a vector of ShVX. However, our studies revealed that GarV-B, GarV-C, GarV-D and GarV-X were transmitted by $A$. tulipae to leek plants, on which populations of the vector achieved the highest growth rate (Kiedrowicz et al. 2017). After infection, yellowstrip mosaic patterns and distortions were observed on the leaves. These four viruses were detected in leek tissues on which populations of A. tulipae developed from adults transferred from infected garlic bulbs. These findings clearly show that the adults of the species had the ability to transmit GarV-B, GarV-C, GarV-D and GarV-X to healthy leek plants.

The confirmation of the ability of A. tulipae to transmit GarV-B, GarV-C, GarV-D and GarV-X is important for understanding the epidemiology of these pathogens. It was proven that $A$. tulipae has the ability to transmit GarV-B, GarV-C, GarV-D and GarV-X, which has been previously reported by Van Dijk et al. (1991), Yamashita et al. (1996), Koo et al. (1998) and Kang et al. (2007).

One of the most important properties of plant viruses is their infectiveness, i.e. their ability to infect plants and move from plants already infected to virus-free plants. The infection of new plants results in an increase in the number of diseased plants, i.e. a rise in disease incidence. It should be noted that plant diseases are noticed and gain significance when they affect a large portion of the plant population. This occurs as a result of virus transmission from one plant to another or from one crop to another. Viruses are unable to actively move to new plants, therefore many of them are transmitted by vectors (Bragard et al. 2013). Despite their slow walking, minute eriophyid mites are known to disperse for long distances on air currents (Michalska et al. 2010). Such a mode of dispersal of $A$. tulipae increases the risk of the transmission of GarV-B, GarV-C, GarV-D and GarV-X from garlic plants to leek plants, which may constitute a threat to the leek crops (Shahraeen et al. 2008). 
The results presented by the authors of this study constitute the first report of the ability of A. tulipae to transmit GarV-B, GarV-C, GarV-D and GarV-X from garlic bulbs to leek plants. Demonstration that A. tulipae can transmit allexiviruses from garlic to leeks indicates a need for additional studies designed to determine the mechanism of transmission.

\section{Compliance with ethical standards}

The research does not involve any human participants and/or animals. The materials in the article have not been published in whole or in part elsewhere and not currently being considered for publication in another journal. All authors have been personally and actively involved in substantive work leading to the manuscript and will hold themselves jointly and individually responsible for its content. The authors bear all the ethical responsibilities of this manuscript.

Conflict of interest The authors declare that they have no conflict of interest.

Open Access This article is licensed under a Creative Commons Attribution 4.0 International License, which permits use, sharing, adaptation, distribution and reproduction in any medium or format, as long as you give appropriate credit to the original author(s) and the source, provide a link to the Creative Commons licence, and indicate if changes were made. The images or other third party material in this article are included in the article's Creative Commons licence, unless indicated otherwise in a credit line to the material. If material is not included in the article's Creative Commons licence and your intended use is not permitted by statutory regulation or exceeds the permitted use, you will need to obtain permission directly from the copyright holder. To view a copy of this licence, visit http://creativecommons.org/licenses/by/4.0/.

\section{References}

Adams, M.J., Antoniw, J.F., Bar-Joseph, M., Brunt, A.A., Candresse, T., Foster, G.D., Martelli, G.P., Milne, R.G., \& Fauquet, C.M. (2004). The new plant virus family Flexiviridae and assessment of molecular criteria for species demarcation. Archives of Virology, 149, 1045-1060.

Almaguel, L., Perez, R., Caceres, I., Feito, E., \& Sanchez, Y.G. (1986). Disinfection of garlic cloves by soaking prior to chemical treatment against Eriophyes (Aceria) tulipae. Ciencia y Tecnica en la Agricultura, 9, 57-72.

Bag, S., Rogers, P., Watson, R., \& Pappu, H.R. (2009). First report of natural infection of garlic with Iris yellow spot virus in the United States. Plant Disease, 93, 839.

Bala, S.C., Karmakar, K., \& Ghosh, S.K. (2015). Population dynamics of mite, Aceria tulipae (Keif.) on garlic (Allium sativum L.) and its management under Bengal Basin.
International Journal of Science. Environment and Technology, 4, 1365-1372.

Bereda, M. (2015). Characterization of allexiviruses - Pathogens of garlic plants (Allium sativum L.). Doctoral thesis. Department of Plant Pathology, Warsaw University of Life Sciences WULS-SGGW. 227 pp.

Bereda, M., \& Paduch-Cichal, E. (2016). Allexiviruses Pathogens of garlic plants Allexiwirusy - Patogeny czosnku pospolitego. Progress in Plant Protection/Postepy $w$ ochronie roślin, 56, 302-311.

Bereda, M., Paduch-Cichal, E., \& Dąbrowska, E. (2017). Occurrence and phylogenetic analysis of allexiviruses identified on garlic from China, Spain and Poland commercially available on the polish retail market. European Journal of Plant Pathology, 149, 227-237.

Boczek, J., \& Chyczewski, J. (1974). The curl mite Aceria tulipae K., a pest of garlic, new to Poland. Ochrona Roślin, 18, 1314.

Boom, R., Sol, C.J., Salimans, M.M., Jansen, C.L., Wertheim-van Dillen, P.M., \& Van der Noordaa, J. (1990). Rapid and simple method for purification of nucleic acids. Journal of Clinical Microbiology, 28, 495-503.

Bragard, C., Caciagli, P., Lemaire, O., Lopez-Moya, J.J., MacFarlane, S., Peters, D., Susi, P., \& Torrance, L. (2013). Status and prospects of plant virus control through interference with vector transmission. Annual Review of Phytopathology, 51, 177-201.

Cafrune, E.E., Balzarini, M., \& Conci, V.C. (2006). Changes in the concentration of an Allexivirus during the crop cycle of two garlic cultivars. Plant Disease, 90, 1293-1296.

Charanasri, V., Saringkaphaibul, C., Kulpiyawat, T., Seriphunpanich, C., \& Wongsiri, N. (1984). Studies on the taxonomy and biology of mites injurious to garlic in Thailand. Proceedings of the 4th conference entomology zoology. Division, Bangkok, Thailand.

Chen, J., \& Chen, J. (2002). Genome organization and phylogenetic tree analysis of Garlic virus $E$, a new member of genus Allexivirus. Chinease Science Bulletin, 47, 33-37.

Chodorska, M., Paduch-Cichal, E., Kalinowska, E., \& Szyndel, M.S. (2014). Assessment of Allexiviruses infection in garlic plants in Poland. Acta Scientiarum Polonorum, Hortorum Cultus, 13, 176-186.

Conci, V.C., Nome, S.F., \& Milne, R.G. (1992). Filamentous viruses of garlic in Argentina. Plant Disease, 76, 594-596.

Courtin, O., Fauvel, G., \& Leclant, F. (2000). Temperature and relative humidity effects on egg and nymphal development of Aceria tulipae (K.) (Acari: Eriophyidae) on garlic leaves (Allium sativum L.). Annals of Applied Biology, 137, 207-211.

de Lillo, E., Craemer, C., Amrine Jr., J.W., \& Nuzzaci, G. (2010). Recommended procedures and techniques for morphological studies of Eriophyoidea (Acari: Prostigmata). Experimental and Applied Acarology, 51, 283-307.

del Estal, P., Arroyo, M., Vinuela, E., \& Budia, F. (1985). Mites that attack garlic crops in Spain. Anales del Instituto Nacional de Investigaciones Agrarias, Agricola, 28, 131-145.

Etoh, T. (1985). Studies on the sterility in garlic Allium sativum L. Memoirs of Faculty of Agriculture Kagawa University, 21, 7-132.

Flechtmann, C.H.W., \& Davis, R. (1971). Seven eriophyid mites new to Georgia including Rhyncaphytoptus nigrans. Journal of the Georgia Entomology Society, 6, 7-9. 
Fujisawa, J. (1989). Loss of garlic yield by double infection of garlic viruses. Agriculture \& Horticulture, 64, 737-741.

Gieck, S.L., Hamm, P.B., David, N.L., \& Pappu, H.R. (2009). First report of Garlic virus $B$ and Garlic virus $D$ in garlic in the Pacific northwest. Plant Disease, 93, 431.

Gispert, C., Oldfield, G.N., Perring, M.T., \& Creamer, R. (1998). Biology of the transmission of peach mosaic virus by Eriophyes insidiosus (Acari: Eriophyidae). Plant Disease, 82, 1371-1374.

González, R., Arretz, P., \& Campos, L. (1973). Catálogo de las plagas agrícolas de Chile. Ciencias Agricolas, Facultad de Agronomia, Universidad de Chile, Santiago. 68 pp.

Granda, R., Landázuri, G., \& Arkhipov, A.V. (2017). First report of Shallot virus $X(\mathrm{ShVX})$ in garlic in Ecuador. Plant Disease, 101, 1066.

Hall, T.A. (1999). BioEdit: A user-friendly biological sequence alignment editor and analysis program for windows 95/98/ NT. Nucleic Acids Symposium Series, 41, 95-98.

Hassan, M.F., Afifi, A.M., \& Nawar, M.S. (1986). Mites inhabiting plants and soil in Sinai and newly reclaimed lands. Bulletin of the Entolomological Society of Egypt, 66, 211225.

Jemal, K., Abraham, A., \& Feyissa, T. (2015). The occurrence and distribution of four viruses on garlic (Allium sativum L.) in Ethiopia. International Journal of Basic and Applied Sciences, 4, 5-11.

Jeppson, L.R., Keifer, H.H., \& Baker, E.W. (1975). Mites injurious to economic plants. University of California Press, Berkeley, California, USA. ISBN 9780520023819.

Kang, S.G., Koo, B.J., Lee, E.T., \& Chang, M.U. (2007). Allexivirus transmitted by eriophyid mites in garlic plants. Journal of Microbiological Biotechnology, 17, 1833-1840.

Keifer, H.H., Baker, E.W., Kono, T., Delfinado, M., \& Styer, W.E. (1982). An illustrated guide to plant abnormalities caused by eriophyid mites in North America. United States Department of Agriculture, Agricultural Research Service, agricultural handbook 573, U.S. government printing office, Washington D.C. 178 pp.

Kiedrowicz, A., Rector, B.G., Lommen, S., Kuczyński, L., Szydło, W., \& Skoracka, A. (2017). Population growth rate of dry bulb mite, Aceria tulipae (Acariformes: Eriophyidae), on agriculturally important plants and implications for its taxonomic status. Experimental and Applied Acarology, 73, $1-10$.

King, A.M.Q., Adams, M.J., Carstens, E.B., \& Lefkowitz, E.J. (2012). Virus taxonomy: Classification and nomenclature of viruses. Ninth report of the International Committee on Taxonomy of Viruses. Elsevier Academic Press: Amsterdam, 1327.

Klukáčková, J., Navrátil, M., \& Duchoslav, M. (2007). Natural infection of garlic (Allium sativum L.) by viruses in the Czech Republic. Journal of Plant Diseases Protection, 114, 97-100.

Knaub, V.Z., \& Buslawa, L.A. (1975). Control measures for Aceria tulipae (Acarina: Eriophyoidea) on garlic in the Moldavian SSR-USSR. Izvestiya Akademii Nauk Moldavskoi SSR Seriya Biologiczeskikh i Khimicheskikh Nauk, 6, 82-84.

Koo, B., Chang, M., \& Choi, D. (1998). Garlic mite-borne virus isolated from cultivated garlic in Korea. Korean Journal of Plant Pathology, 14, 136-144.
Krzymińska, A. (2008). Ozdobne gatunki i odmiany czosnku (Allium). Analiza genetyczna i mikromorfologiczna. Metody pędzenia roślin. Rozprawy Naukowe, 392, 65.

Kulkarni, N.K., Kumar, P.L., Muniyappa, V., Jones, A.T., \& Reddy, D.V.R. (2002). Transmission of pigeon pea sterility mosaic virus by the Eriophyid mite, Aceria cajani (Acari: Arthropoda). Plant Disease, 86, 1297-1302.

Lanzoni, C., Ratti, C., Turina, M., Pisi, A., Tedeschi, P., \& Autonell, C.R. (2006). Molecular characterisation of Allexiviruses from garlic in Italy. Journal of Plant Pathology, 88, 47.

Larrain, S.P. (1986). Incidence of attack by the bulb mite Eriophyes tulipae Keifer (Acari, Eriophyidae) on the yield and quality of garlic (Allium sativum L.). Chilean Journal of Agricultural Research, 46, 147-150.

Liro, J.I., \& Roivainen, H. (1951). Suomen eläimet (Animalia Fennica) 6. Äkämäpunkit (Eriophyidae). [Fauna of Finland (Animalia Fennica) 6. Gall mites (Eriophyidae).] Vanamo, Turku, Finland, 281 pp.

Malinowski, T. (1997). Silica capture-reverse transcription-polymerase chain reaction (SC-RT-PCR): Application for the detection of several plant viruses. Diagnosis and Identification of Plant Pathogens, 11, 445-448.

Manson, D.C.M. (1970). The spider mite family Tetranychidae in New Zealand. V. Tetranychus (Tetranychus) moutensis a new species of spider mite from flax (Phormium tenax Forst.). New Zealand Journal of Science, 13, 323-327.

Michalska, K., Skoracka, A., Navia, D., \& Amrine, J.W. (2010). Behavioural studies on eriophyoid mites: An overview. Experimental and Applied Acarology, 51, 39-51.

Mituti, T., Moura, M.F., Marubayashi, J.M., Oliveira, M.L., Imaizumi, V.M., Sakate, R.K., \& Pavan, M.A. (2015). Survey of viruses belonging to different genera and species in noble garlic in Brazil. Scientia Agricola, 72, 278-281.

Orlob, G.B. (1966). Feeding and transmission characteristics of Aceria tulipae Keifer as vector of wheat streak mosaic virus. Phytopathologische Zeitschrift, 55, 218-238.

Paliwal, Y.C. (1980). Relationship of wheat streak mosaic and barley stripe mosaic viruses to vector and nonvector eriophyid mites. Archives of Virology, 63, 123-132.

Perotto, M.C., Cafrune, E.E., \& Conci, V.C. (2010). The effect of additional viral infections on garlic plants initially infected with Allexiviruses. European Journal of Plant Pathology, 126, 489-495.

Proeseler, G. (1969). Zur Übertragung des Feigenmosaikvirus durch die Gallmilbe Aceria ficus Cotte. Zentralblatt für Bakteriologie, Parasitenkunde, Infektionskrankheiten und Hygiene, 123, 288-292.

Proeseler, G. (1972). Beziehungen zwischen Virus, Vektor und Wirstpflanze am Beispiel des Feigenmosaik-Virus und Aceria ficus Cotte (Eriophyoidea). Acta Phytopathologica Academiae Scientiarium Hungaricae, 7, 106-179.

Rossetto, C.J. (1972). Ácaros eriofiídios pragas de fruteiras e outras plantas no Brasil. Ciência e Cultura, 24, 817-829.

Sako, I., Osaki, T., Nakasone, W., \& Inouye, T. (1991). Yellow mosaic of rakkyo (Allium chinense G. Don) caused by Tobacco mosaic virus and Garlic latent virus and its occurence in the field. Proceedings of the Kansai Plant Protection Society, 33, 21-28.

Sapáková, E., Hasíková, L., Hřivna, L., Stavělíková, H., \& Šefrová, H. (2012). Infestation of different garlic varieties 
by dry bulb mite Aceria tulipae (Keifer) (Acari: Eriophyidae). Acta Universitatis Agriculturae et Silviculturae Mendelianae Brunensis, 60, 293-301.

Shahraeen, D.E., Lesemann, T., \& Ghotbi, N. (2008). Survey for viruses infecting onion, garlic and leek crops in Iran. EPPO Bulletin, 38, 131-135.

Simon, P.W., \& Jenderek, M.M. (2003). Flowering, seed production and the genesis of garlic breeding. Plant Breeding Reviews, 32, 211-244.

Singh, P., Prabha, K., Jain, R.K., \& Baranwal, V.K. (2014). Nterminal in coat protein of Garlic virus $X$ is indispensible for its serological detection. Virus Genes, 48, 128-132.

Slykhuis, J.T., \& Paliwal, Y.C. (1972). Ryegrass mosaic virus. CMI/AAB Descriptions of Plant Viruses, 86.

Stefanac, Z. (1980). Cucumber mosaic virus in garlic. Acta Botanica Croatica, 39, 21.

Sward, R.J. (1990). Lettuce necrotic yellow rhabdovirus and viruses infecting garlic. Australasian Plant Pathology, 19, 46-51.

Takaichi, M., Nagakubo, T., \& Oeda, K. (2001). Mixed virus infections of garlic determined by a multivalent polyclonal antiserum and virus effects on disease symptoms. Plant Disease, 85, 71-75.

Tamura, K., Peterson, D., Peterson, N., Stecher, G., Nei, M., \& Kumar, S. (2011). MEGA5: Molecular evolutionary genetics analysis using maximum likelihood, evolutionary distance, and maximum parsimony methods. Molecular Biology and Evolution, 28, 2731-2739.
The ICTV Online (10th) Report on Virus Taxonomy. 2016. International Committee on Taxonomy of Viruses (ICTV) https://talk.ictvonline.org/.

Van Dijk, P., Verbeek, M., \& Bos, I. (1991). Mite-borne virus isolates from cultivated Allium species, and their classification into two new rymoviruses in the family Potyviridae. Netherlands Journal of Plant Pathology, 97, 381-399.

Van Dijk, P. (1993). Survey and characterization of potyviruses and their strains in Allium species. Netherlands Journal of Plant Pathology, 99, 1-48.

Van Dijk, P., \& Van der Vlugt, R.A.A. (1994). New mite-borne virus isolates from rakkyo, shallot and wild leek species. European Journal of Plant Pathology, 100, 269-277.

Walkey, D.G.A. (1990). Virus diseases. Rabinowitch H.D, Brewster J.L, eds. Onions and allied crops, Vol. II. CRC press, Boca Raton, FL: 191-212.

Ward, L.I., Perez-Egusquiza, Z., Fletcher, J.D., \& Clover, G.R.G. (2009). A survey of viral diseases of Allium crops in New Zealand. Australasian Plant Pathology, 38, 533-539.

Wylie, S.J., Luo, H., Li, H., \& Jones, M.G. (2012). Multiple polyadenylated RNA viruses detected in pooled cultivated and wild plant samples. Archives of Virology, 157, 271-284.

Yamashita, K., Sakai, J., \& Hanada, K. (1996). Characterization of a new virus from garlic (Allium sativum L.), garlic mite-borne mosaic virus. Annals of the Phytopathological Society of Japan, 62, 483-489. 